\title{
Cretaceous stage boundaries - Introduction
}

https://doi.org/10.37570/bgsd-1984-33-33

In October 1983, the Subcommission on Cretaceous Stratigraphy arranged a symposium on Cretaceous Stage Boundaries in Copenhagen to fulfil the Subcommission's primary responsibility: the defining of stage boundaries.

Some hundred participants attended the symposium and sixty-two contributions on Cretaceous stratigraphy were discussed (Birkelund, T., Bromley, R., Christensen, W. K., Håkansson, E., Surlyk, F. (eds), 1983: Abstracts. Cretaceous Stage Boundaries Symposium, Copenhagen. $210 \mathrm{pp}$ ).

Most of the papers presented at the symposium resulted from the activity of three working groups, established by the Subcommission in 1977:

1. Working group on the Pre-Albian Stages (chairman: P. F. Rawson).

2. Working group on the Albian-Turonian Stages (chairman: F. Robaszynski).

3. Working group on the Coniacian-Maastrichtian Stages (chairman: F. Schmid).

A number of papers were based on the results of the IGCP project Mid-Cretaceous Events and others on the work of regional working groups.

The present symposium volume contains a number of contributions of general stratigraphic significance. Other papers presented at the symposium, principally those of regional importance, will be published in CRETACEOUS RESEARCH.

In order to reach a consensus on the definition of the Cretaceous stage boundaries, a major part of the symposium was devoted to discussions centred around the three working groups of the Subcommission. On the basis of the discussion, the chairmen and their secretaries formulated a set of stage boundary proposals and recommendations for each group of stages. These recommendations were discussed in plenum on the last day of the symposium.

The introductory paper in the present volume is a synthesis both of the view-points on stage boundaries expressed at the plenum discussion and of other contributions in this book. It is our hope that this synthesis will provide guidelines for the final choice of the Cretaceous stage boundaries.

\section{Tove Birkelund}

Chairman of the Subcommision on Cretaceous Stratigraphy

Finn Surlyk

Secretary of the Subcommission on Cretaceous Stratigraphy 